\title{
Postoperative Analgesia Time in Dogs Submitted to Mastectomy and Anesthetized with Tumescent Solutions of Lidocaine or Ropivacaine*
}

\author{
Fabiana Del Lama Rocha ${ }^{1,5}$, Newton Nunes ${ }^{1,5}$, Paula Chiconi Dacunto dos Santos ${ }^{2}$, \\ Cléber Kazuo Ido 1,5, Paloma do Espírito Santo Silva ${ }^{3}$, Eveline Simões Azenha Aidar, ${ }^{1,5}$, \\ Helen Roberta Amaral da Silva ${ }^{1,5}$ \& Tiago Carmagnani Prada ${ }^{4}$
}

\begin{abstract}
Background: Mastectomy, a procedure with high pain stimulation, is the treatment of choice for bitches with breast cancer. Tumescent anaesthesia is widely used for transoperative and postoperative analgesia in bitches submitted to mastectomy, because facilitates tissue divulsion, also contributing significantly for the rapid recovery of patients. Although, there is no consensus as to which local anesthetic to use and at what concentration it should be used. Herein was investigated which local anesthetics, lidocaine or ropivacaine, when used in tumescent solutions, could provide a more lasting analgesic effect in the postoperative period in bitches submitted to radical unilateral mastectomy.

Materials, Methods \& Results: Sixteen bitches were sedated with chlorpromazine $(0.3 \mathrm{mg} / \mathrm{kg})$ and meperidine $(3 \mathrm{mg} / \mathrm{kg})$ followed by anesthesia with propofol and isofluorane. Then, bitches were randomly assigned to two groups ( $\mathrm{n}=8$ each): $\mathrm{LG}$ group, infused with $15 \mathrm{~mL} / \mathrm{kg}$ of tumescence solution containing $0.1 \%$ lidocaine; and RG group, infused with $15 \mathrm{~mL} / \mathrm{kg}$ of tumescence solution with $0.1 \%$ ropivacaine. The study was conducted in a double-blind fashion. Control group did not include, because the patients would be submitted to severe or unbearable pain, according to the short-form of the Glasgow pain Scale (CMPS-SF). The heart (HR) and respiratory $(f)$ rates, and systolic blood pressure (SBP) were measured in the pre-operative period and immediately after extubation (Mextub) and at $0.5 \mathrm{~h}, 1 \mathrm{~h}, 2 \mathrm{~h}, 4 \mathrm{~h}, 8 \mathrm{~h}$, and $12 \mathrm{~h}$ after the extubation. Analgesic efficacy was assessed using the CMPS-SF and von Frey filaments. Both groups showed higher means for $\mathrm{HR}$ at $0.5 \mathrm{~h}(167 \pm 7 \mathrm{in} \mathrm{LG;} 170 \pm 7 \mathrm{in} \mathrm{RG)}$ than at $4 \mathrm{~h}(117 \pm 7$ in LG; $120 \pm 7 \mathrm{in} \mathrm{RG).} \mathrm{CMPS-SF} \mathrm{revealed} \mathrm{higher} \mathrm{medi-}$ ans $(P=0.038)$ at the Mextub and $12 \mathrm{~h}$ time points for the LG [5 (3-6) and $1(0-2)]$ than for the RG [5 (2-5) and $0(0-1)]$. Discussion: Pain was excluded as a possible explanation for the difference presented for HR in both groups because, moderate pain is considered when more than two cardiorespiratory parameters show an increase of at least $20 \%$ in relation to baseline values, which did not occur in this study. Indeed, most animals were walking at $0.5 \mathrm{~h}$ after extubation and, in many cases, this occurred before the collection of data for the postoperative period. This may have influenced the results since exercise releases catecholamines and increases HR. Moreover at $4 \mathrm{~h}$ after extubation, most animals were asleep. As metabolism decreases during sleep, expected that HR would also decrease and that was indeed the case. Regarding CMPS-SF, the way the patients walks was the item that most contributed to the high score found for the Mextub time point because it's impossible to be performed seconds after extubation. As the reluctance to move occurred only immediately after extubation, the values obtained at the Mextub time point are more likely to be due to an anesthetic residual effect and not to the pain stimulus itself. When the groups were compared, the median values obtained at the LG were greater than $\mathrm{RG}$ at the Mextub and $12 \mathrm{~h}$ postoperative time points. There was no need for analgesic rescue differing from those in literature that reported the need for analgesic rescue in 50\% of the animals. Those study established a CMPS-SF score of 3.3 as indicative for analgesic rescue whereas our research established a score of 7 . Tumescence solutions with lidocaine or ropivacaine provide equivalent postoperative analgesia for at least $12 \mathrm{~h}$.
\end{abstract}

Keywords: tumescent local anesthesia, local anesthetic, dogs, pain, breast neoplasm.

*Article based on a Thesis submitted by the senior author in partial fulfillment of requirements for the Master of Science Degree. ${ }^{1}$ Programa de PósGraduação em Cirurgia Veterinária \& ${ }^{5}$ Departamento de Clínica e Cirurgia Veterinária (DCCV), Faculdade de Ciências Agrárias e Veterinárias (FCAV), Unesp, Jaboticabal, SP, Brazil. ${ }^{2}$ DomVet Clínica Veterinária, Araraquara, SP. ${ }^{3}$ Força Aérea Brasileira (FAB), Pirassununga, SP. ${ }^{4}$ M.V. autônomo, Jaboticabal. CORRESPONDENCE: F.D.L. Rocha [fabiana.dellama@gmail.com]. Departamento de Clínica e Cirurgia Veterinária - FCAV - Unesp. Via de Acesso Prof. Paulo Donato Castellane s/n. CEP 14884-900 Jaboticabal, SP, Brazil. 


\section{INTRODUCTION}

Breast tumor is the most common neoplasm in dogs, affecting between 36.3 and $50 \%$ of the canine population over 6 years of age. The disease requires the excision of the entire mammary chain in order to provide a better chance of cure [10,11,27]. This surgery is a highly invasive and painful procedure, which requires the use of methods to control pain and bleeding during the transoperative period [8], which is done by associating general inhalation anesthesia with locoregional anesthesia.

Postoperative analgesia is of paramount importance, as catecholamines and cortisol are released in painful processes, thus leading to peripheral vasoconstriction, tissue hypoxia, immunosuppression, gluconeogenesis, and protein catabolism, all of which further slow tissue repair and, consequently, the recovery of patients $[19,20,29,30]$.

The Tumescent anaesthesia technique besides guarantee transoperative and postoperative analgesia also reduces surgical bleeding and facilitates tissue divulsion $[8,12]$. Although these benefits are known, there is no consensus among the scientific community as to which local anesthetic to use and at what concentration it should be used. Indeed, there are reports of using lidocaine (the most commonly used local anesthetic) between $0.32 \%$ and $0,08 \%$ [1,3,8,13,16,31], and studies exploring ropivacaine (shorter latency and a longer duration of action than lidocaine) $0.1 \%$ and $0.05 \%[2,5,16]$.

The aim of this study was to determine which local anesthetic, lidocaine or ropivacaine, when used in tumescent solutions, would provide a more lasting analgesic effect in the postoperative period of bitches submitted to radical unilateral mastectomy.

\section{MATERIALS AND METHODS}

\section{Animals}

Sixteen dogs with breast cancer were included, without racial standardization, aged over seven years, weighing between 4 and $20 \mathrm{~kg}$, and classified as ASA I or II according to the criteria established by the American Society of Anesthesiologists. The patients underwent preoperative examinations, such as basic physical examination, laboratory tests involving blood count, serum creatinine, and alanine aminotransferase. Electrocardiogram evaluation and metastasis research by means of chest radiography in three projections (lateral right, lateral left, and ventro-dorsal) and abdominal ultrasound were also performed. Only patients without comorbidities, such as lung metastasis or abdominal cavity, advanced cardiomyopathy, nephropathy, among other conditions, were included in the study.

The dogs were randomly assigned to two groups of 8 animals each: the lidocaine group (LG) that received tumescent solutions with $0.1 \%$ lidocaine and the ropivacaine group $(\mathrm{RG})$ that received $0.1 \%$ ropivacaine. The study was conducted in a double-blind fashion. Control group was not included in the present study, using a placebo instead of tumescent solution, because the patients would be submitted to severe (above 13 points) or unbearable (above 19 points) pain, according to the short-form of the Glasgow pain Scale (CMPS-SF) [24].

\section{Preparation of solutions}

To prepare the tumescence solution of $0.1 \%$ lidocaine, $12.5 \mathrm{~mL}$ from a flask containing $250 \mathrm{~mL}$ of lactated ringer solution was removed, previously cooled to $8-12^{\circ} \mathrm{C}$, and then added $12.5 \mathrm{~mL}$ of $2 \%$ lidocaine without vasoconstrictor (Lidocaine hydrochloride $2 \%)^{1}$ plus $0.5 \mathrm{~mL}$ of adrenaline $\left(\text { Adren }^{\circledR}\right)^{2}$.

To prepare the tumescence solution of $0.1 \%$ ropivacaine, $25 \mathrm{~mL}$ from a flask containing $250 \mathrm{~mL}$ of lactated ringer solution was removed, previously cooled to $8-12^{\circ} \mathrm{C}$, and then added $25 \mathrm{~mL}$ of $1 \%$ ropivacaine without vasoconstrictor (Ropi $\left.{ }^{\circledR} 1 \%\right)^{3}$ plus 0.5 $\mathrm{mL}$ of adrenaline ${ }^{2}$.

\section{Experimental design}

Before the surgical procedure, patients were subjected to an 8-hour fast without water deprivation [4].

Baseline measurements of heart rate (HR), respiratory rate $(f)$ and systolic blood pressure (SBP) occurred before the sedation of animals. Then, preanesthetic medication using chlorpromazine (Chlorpromazine Hydrochloride $-0.3 \mathrm{mg} / \mathrm{kg}$ ) 1 in association with meperidine (Pethidine Hydrochloride - $3 \mathrm{mg} / \mathrm{kg}$ ) ${ }^{4}$ was administered intramuscularly.

After $20 \mathrm{~min}$, sedation was established, and catheterization of the cephalic vein was performed. Anesthetic induction was performed with propofol (Propovan $\left.{ }^{\circledR}\right)^{3}$ using a sufficient amount to allow orotracheal intubation. Then the orotracheal tube was connected to the inhalation anesthesia machine (SAT 
$500-\mathrm{K})^{5}$ to maintain the anesthesia of patients with isofluorane (Isoforine $\left.{ }^{\circledR}\right)^{3}$, using a calibrated vaporizer, under spontaneous ventilation. Isofluorane was administered at a concentration sufficient to maintain the animal in Plan 2 of the third stage, respecting the parameters established by Guedel and modified by Massone [23]. A mixture of oxygen and compressed air was used as diluent, thus providing the animals with an inspired oxygen fraction $\left(\mathrm{FiO}_{2}\right)$ of 0.6.

The bitches were placed in the supine position on an active thermal mattress and the tumescent solution was applied to the subcutaneous tissue, with the aid of a Klein cannula (Klein needle for syringe 20 $\mathrm{mL} / 20 \mathrm{~cm})^{6}$, at a fixed volume of $15 \mathrm{~mL} / \mathrm{kg}$. Using a scalpel blade number 24 , a small incision was made below the third breast to allow the introduction of the instrument, which has a blunt tip. Then, half the volume of the solution was infused towards the cranial breasts through this opening while the other half was infused towards the caudal breasts. To avoid contamination, the anesthetic solution intended for tumescence was administered following guidelines [21]. Mastectomy started 30 min after the administration of the tumescent solution.

During the transoperative period, patients were monitored with the aid of a multiparametric monitor (DX-2020D-C $)^{7}$, by positioning electrodes and sensors.

The administration of the inhalation anesthetic was interrupted at the end of the surgeries. The patients' extubation time was observed before animals were transferred to the recovery room and the evaluations of the postoperative period initiated. Measurements of cardiorespiratory parameters and pain scores occurred immediately after extubation (Mextub) and $30 \mathrm{~min}(0.5$ h), 1 h, 2 h, 4 h, 8 h, and $12 \mathrm{~h}$ after extubation. HR, $f$, and SBP using the vascular doppler ultrasonic device (DV 610)8 were measured. Pain score evaluation was performed using the short-form Glasgow Composite Measure Pain Scale (CMPS-SF) [25,26] and von Frey filaments [1], as described below.

The CMPS-SF scale ranges from zero to 24 . The higher the score, the greater the patient's pain. The evaluation of the mechanical nociceptive threshold with von Frey filaments was performed with the patients in the supine position, always starting with the thinner filament (number 1), pressing on the cutaneous region throughout the operated extension, always at 0.5 and $2 \mathrm{~cm}$ from the edge of the wound, on both sides.
Pain response was considered positive when vocalization, contraction of the abdominal muscles, movement of the head towards the pressed site, and hostility reactions such as attempts to bite, growl, howl, cry, scream or sudden movements were observed. When a positive response was detected, the filament number was recorded, as well as the time when it occurred. When a positive response to pain was not obtained with the thinner filament, the filament was replaced by a thicker one for further evaluation, until a positive response to pain or its absence was found.

If analgesic rescue were needed, methadone hydrochloride would be injected intramuscularly

If analgesic rescue were needed, methadone hydrochloride $\left(\text { Mytedom }{ }^{\circledR}-0.2 \mathrm{mg} / \mathrm{kg}\right)^{3}$ would be injected intramuscularly. The need for analgesic rescue was identified when the CMPS-SF scale was equal to or greater than 7, as described previously [24]: scores 0-6 considered as mild pain, 7-12 indicated moderate pain, 13-18 severe pain, and 19-24 unbearable pain. Tramadol hydrochloride $\left(\text { Tramadon }^{\circledR}\right)^{3}$ was administered subcutaneously at a dose of $2 \mathrm{mg} / \mathrm{kg}$ in all animals at the final time point $(12 \mathrm{~h})$, even in the absence of signs of pain.

\section{Statistical analysis}

The continuous quantitative variables studied (HR, SBP, and $f$ ) were evaluated by analysis of variance (ANOVA) and those showing significant differences in the means were compared by the Tukey test at the significance level of $5 \%(P \leq 0.05)$. For categorical variables (pain assessment using the CMPS-SF and von Frey filaments), the Kruskal-Wallis and Mann-Whitney test (nonparametric) was used. Differences between the medians were considered significant when $P \leq 0.05$.

\section{RESULTS}

There was no statistical difference $(P<0.05)$ regarding the $\mathrm{HR}$ variable between the groups $\mathrm{LG}$ and $\mathrm{RG}$, but it was noted that $30 \mathrm{~min}(0.5 \mathrm{~h})$ after extubation, both groups presented means higher than the other time points. Regarding the LG, the means found for $\mathrm{HR}$ at $0.5 \mathrm{~h}(167 \pm 7)$ after extubation was greater than the measurements taken at $4 \mathrm{~h}(117 \pm 7)$ and $12 \mathrm{~h}$ $(126 \pm 7)$. Regarding the RG, the means for HR at 0.5 $\mathrm{h}(170 \pm 7)$ after extubation was greater measurements at $2 \mathrm{~h}(118 \pm 7), 4 \mathrm{~h}(121 \pm 7)$ and $8 \mathrm{~h}(132 \pm 7)$ after extubation (Table 1). 
There were no statistical differences $(P>0.05)$ between groups in SBP and respiratory rate (Table 1).

Assessment of pain using the CMPS-SF revealed that the medians for the Mextub time point were higher than all the other postoperative time points for both groups. When the groups were compared, the median values $(P=0.038)$ obtained at the LG $(5[3$
- 6] and $1[0$ - 2]) were greater than RG (5 [2 - 5] and $0[0-1])$ at the Mextub and $12 \mathrm{~h}$ postoperative time points (Table 2).

Regarding pain assessment with von Frey's filaments, no statistical differences $(P>0.05)$ was found between LG and RG groups nor between the time points within the groups (Table 2).

Table 1. Mean values and standard deviation of the variables heart rate (HR), systolic blood pressure (SBP), and respiratory rate ( $f$ ), in the pre- and post-operative periods of bitches submitted to radical unilateral mastectomy, under general inhalation anesthesia, in association with tumescent solutions containing $0.1 \%$ lidocaine (LG) or $0.1 \%$ ropivacaine $(\mathrm{RG})$.

\begin{tabular}{|c|c|c|c|c|c|c|}
\hline \multirow{3}{*}{$\begin{array}{c}\text { Variable } \\
\text { Time points }\end{array}$} & \multicolumn{2}{|c|}{ HR (bpm) } & \multicolumn{2}{|c|}{$\mathrm{SBP}(\mathrm{mmHg})$} & \multicolumn{2}{|c|}{$f(\mathrm{mpm})$} \\
\hline & \multicolumn{2}{|c|}{ Group } & \multicolumn{2}{|c|}{ Group } & \multicolumn{2}{|c|}{ Group } \\
\hline & LG & RG & LG & RG & LG & RG \\
\hline Baseline & $142 \pm 7^{\mathrm{ab}}$ & $150 \pm 7^{\mathrm{ab}}$ & $115 \pm 7.94$ & $135 \pm 8.71$ & $27 \pm 5$ & $35 \pm 5$ \\
\hline Mextub & $142 \pm 7^{\mathrm{ab}}$ & $146 \pm 7^{\mathrm{ab}}$ & $110 \pm 8$ & $121 \pm 6.78$ & $42 \pm 6$ & $33 \pm 6$ \\
\hline $0.5 \mathrm{~h}$ & $167 \pm 7^{\mathrm{a}}$ & $170 \pm 7^{\mathrm{a}}$ & $119 \pm 6.78$ & $120 \pm 7.28$ & $35 \pm 5$ & $35 \pm 5$ \\
\hline $1 \mathrm{~h}$ & $156 \pm 7^{\mathrm{ac}}$ & $141 \pm 7^{\mathrm{ab}}$ & $116 \pm 7.34$ & $119 \pm 7.28$ & $31 \pm 5$ & $34 \pm 5$ \\
\hline $2 \mathrm{~h}$ & $137 \pm 7^{\mathrm{ab}}$ & $118 \pm 7^{\mathrm{b}}$ & $124 \pm 7.34$ & $127 \pm 6.78$ & $34 \pm 5$ & $39 \pm 6$ \\
\hline $4 \mathrm{~h}$ & $117 \pm 7^{b}$ & $121 \pm 7^{b}$ & $135 \pm 6.78$ & $131 \pm 6.78$ & $33 \pm 5$ & $41 \pm 5$ \\
\hline $8 \mathrm{~h}$ & $132 \pm 7^{\mathrm{ab}}$ & $132 \pm 7^{b}$ & $147 \pm 6.78$ & $134 \pm 6.78$ & $31 \pm 5$ & $42 \pm 6$ \\
\hline $12 \mathrm{~h}$ & $126 \pm 7^{\mathrm{bc}}$ & $133 \pm 7^{\mathrm{ab}}$ & $129 \pm 6.78$ & $141 \pm 6.78$ & $34 \pm 5$ & $43 \pm 5$ \\
\hline
\end{tabular}

Baseline: before the pre-anesthetic medication; Mextub: immediately after extubation; $30 \mathrm{~min}(0.5 \mathrm{~h}), 1 \mathrm{~h}, 2 \mathrm{~h}, 4 \mathrm{~h}, 8 \mathrm{~h}$, and $12 \mathrm{~h}$ after extubation. Means followed by different lower case letters in the columns indicate significant differences at $P<0.05$.

Table 2. Medians and first and third quartile of the total sum of points of the pain score, assessed by the short-form of the Glasgow pain Scale (CMPS-SF) and the strength, in grams (g), exerted by the von Frey filaments, during the postoperative period of bitches submitted to radical unilateral mastectomy, under general inhalation anesthesia in association with tumescence solutions containing $0.1 \%$ lidocaine $(\mathrm{LG})$ or $0.1 \%$ ropivacaine $(\mathrm{RG})$.

\begin{tabular}{|c|c|c|c|c|}
\hline \multirow{3}{*}{$\begin{array}{c}\text { Variable } \\
\text { Time points }\end{array}$} & \multicolumn{2}{|c|}{ CMPS-SF } & \multicolumn{2}{|c|}{ von Frey Filaments } \\
\hline & \multicolumn{2}{|c|}{ Group } & \multicolumn{2}{|c|}{ Group } \\
\hline & LG & RG & LG & RG \\
\hline Mextub & $5[3-6]^{\mathrm{Aa}}$ & $5[2-5]^{\mathrm{Ba}}$ & $65[65-65]$ & $65[65-65]$ \\
\hline $0.5 \mathrm{~h}$ & $1[0-3]^{\mathrm{b}}$ & $1[0-5]^{\mathrm{b}}$ & $65[65-65]$ & $65[28-65]$ \\
\hline $1 \mathrm{~h}$ & $1[0-2]^{\mathrm{b}}$ & $1[0-1]^{\mathrm{b}}$ & $65[65-65]$ & $65[65-65]$ \\
\hline $2 \mathrm{~h}$ & $1[0-1]^{\mathrm{b}}$ & $1[0-3]^{\mathrm{b}}$ & $65[65-65]$ & $65[28-65]$ \\
\hline $4 \mathrm{~h}$ & $1[0-2]^{\mathrm{b}}$ & $1[0-2]^{\mathrm{b}}$ & $65[10-65]$ & 65 [28 - 65] \\
\hline $8 \mathrm{~h}$ & $1[0-2]^{\mathrm{b}}$ & $1[0-3]^{\mathrm{b}}$ & $65[8-65]$ & $65[20-65]$ \\
\hline $12 \mathrm{~h}$ & $1[0-2]^{\mathrm{Ab}}$ & $0[0-1]^{\mathrm{Bb}}$ & $65[20-65]$ & $65[10-65]$ \\
\hline
\end{tabular}

Mextub: Immediately after extubation; $30 \mathrm{~min}(0.5 \mathrm{~h}), 1 \mathrm{~h}, 2 \mathrm{~h}, 4 \mathrm{~h}, 8 \mathrm{~h}$, and $12 \mathrm{~h}$ after extubation.Medians followed by different capital letters in the lines differ from each other according to the Mann-Whitney test, $P<0.05$. Medians followed by different lowercase letters in the columns indicate significant differences from each other by the Kruskall-Wallis test at $P<0.05$.

\section{DISCUSSION}

Regarding HR, pain was excluded as a possible explanation of higher means at $30 \mathrm{~min}(0.5 \mathrm{~h})$ after extubation in both groups because, according to other studies [15], moderate pain is considered when more than two cardiorespiratory parameters show an increase of at least $20 \%$ in relation to baseline values, which did not occur in this study. In addition, analgesic rescue, based on the CMPS-SF results, did not present a score suggestive of pain $30 \mathrm{~min}(0.5 \mathrm{~h})$ after extubation in both LG and RG groups (Table 2). A more likely explanation came from the analysis of individual pa- 
tients. Indeed, most animals were walking at $0.5 \mathrm{~h}$ after extubation and, in many cases, this occurred before the collection of data for the postoperative period. This may have influenced the results since exercise releases catecholamines and increases HR [17].

At $4 \mathrm{~h}$ after extubation, most animals were asleep. As metabolism decreases during sleep [18], it was expected that HR would also decrease and that was indeed the case (Table 1). The means obtained for SBP in both LG and RG (Table 1) were within the values considered normal for adult dogs [6], reinforcing the analgesic properties of the tumescence solutions used in this study. Although respiratory depression during the postoperative period following the use of opioids [22] and isofluorane [7] is not uncommon, this condition was not observed since the means for $f$ measurements obtained for both groups (Table 1) were within the reference values for dogs [14].

Evaluation of the pain score with the CMPS-SF is simple and allows the evaluator to quickly become familiar with the evaluation method [26]. Compared to other scales, the CMPS-SF is more sensitive regarding the need for analgesic rescue during the postoperative period of mastectomies; thus, eventual inexperience of the evaluator does not compromise the quality of the evaluations [9].

The item that most contributed to the CMPSSF high score found for the Mextub time point was the "B-III", which assesses the way the patient walks (impossible to be performed seconds after extubation). Indeed, it is known that sedation alters some behavioral manifestations, such as walking, thus making it difficult to differentiate whether the absence of movement is due to pain or sedation [28]. As the reluctance to move occurred immediately after extubation and, since the patients were walking normally without having performed analgesic rescue at the time of $0.5 \mathrm{~h}$, the values obtained at the Mextub time point are more likely to be due to an anesthetic residual effect and not to the pain stimulus itself.

None of the pain scores obtained indicated the need for analgesic rescue (Table 2). These results differ from those reported by researchers who also compared tumescent solutions with the same local anesthetics tested herein, albeit at different concentrations $(0.32 \%$ lidocaine and $0.1 \%$ ropivacaine) [16]. They reported the need for analgesic rescue in $50 \%$ of the animals of each anesthetic group at CMPS-SF score of 3.3 whereas our research established a score of 7 as indica- tive for analgesic rescue. Studies in bitches submitted to mastectomy and using tumescent solutions with $0.32 \%$ lidocaine [1] and $0.05 \%$ or $0.1 \%$ ropivacaine [2] reported painful sensitivity and need for analgesic rescue 7 hours after administration of the solutions. It is difficult to compare their results with those presented herein as they also used in their analyzes the data of bitches submitted to bilateral mastectomy, a procedure that is more painful than unilateral mastectomy.

Our results regarding pain assessment with von Frey's filaments (Table 2) corroborate the findings of Abimussi [1], who evaluated the return of skin sensitivity of patients using a tumescent solution with lidocaine $0.32 \%$ and ropivacaine $0.1 \%$ or $0.05 \%$. Moreover, response to painful stimuli was not observed in any of the filaments (including the number 15, which is the thickest and corresponds to $65 \mathrm{~g}$ of strength) at $12 \mathrm{~h}$ after extubation (Table 2). However, our results differ from the data presented by other researchers because they observed patients' sensitivity to von Frey filaments $7 \mathrm{~h}$ after using the tumescent solution containing ropivacaine $0.1 \%$ or $0.05 \%$ [2].

Although there is no statistical difference in the CMPS-SF between the groups, the solution with ropivacaine tended to contribute to a lower degree of sedation soon after extubation and a longer duration of the analgesic effect in the postoperative period than the solution with lidocaine.

\section{CONCLUSION}

Both tumescence solutions tested herein, with $0.1 \%$ lidocaine and the $0.1 \%$ ropivacaine, provide postoperative analgesia for at least $12 \mathrm{~h}$ and are useful as adjuvants to general inhalation anesthesia in mastectomies of bitches.

\section{MANUFACTURERS}

${ }^{1}$ Hypofarma Instituto de Hypodermia e Farmacia Ltda. Ribeirão das Neves, MG, Brazil.

${ }^{2}$ Hipolabor Farmacêutica Ltda. Belo Horizonte, MG, Brazil.

${ }^{3}$ Cristália Produtos Químicos Farmacêuticos Ltda. Campinas, SP, Brazil.

${ }^{4}$ União Química Farmacêutica Nacional S.A. Taboão da Serra, SP, Brazil.

${ }^{5}$ Takaoka Indústria e Comércio Ltda. São Bernardo do Campo, SP, Brazil.

${ }^{6}$ Härte Instrumentos Cirúrgicos Ltda. Ribeirão Preto, SP, Brazil.

${ }^{7}$ Dixtal Biomédica Indústria e Comércio Ltda. Manaus, AM, Brazil.

${ }^{8}$ Medmega Indústria de Equipamentos Médicos Ltda. Franca, SP, Brazil. 
Ethical approval. This study was approved by the Ethics Committee on the Use of Animals (CEUA), under the protocol No. $1560 / 17$.
Declaration of interest. The authors report no conflicts of interest. The authors alone are responsible for the content and writing of paper.

\section{REFERENCES}

1 Abimussi C.J.X. 2012. Anestesia por tumescência com lidocaína ou ropivacaína em diferentes concentrações em cadelas submetidas à mastectomia. 75f. Botucatu, SP. Dissertação (Mestrado em Anestesiologia) - Programa de PósGraduação em Anestesiologia, Universidade Estadual Paulista "Julio de Mesquita Filho", Campus Botucatu.

2 Abimussi C.J.X., Menegheti T.M., Wagatsuma J.T., Floriano B.P., Arruda A.M.M., dos Santos P.S.P. \& Oliva V.N.L.S. 2014. Tumescent local anesthesia with ropivacaine in different concentrations in bitches undergoing mastectomy: plasma concentration and post-operative analgesia. Veterinary Anaesthesia and Analgesia. 41(5): 516-525.

3 Aguirre C.S., Minto B.W., Faria E.G., Horr M., Filgueira F.G.F. \& Nardi AB. 2014. Conventional anesthesia and tumescent technique in bitches which underwent mastectomy. Evaluation of postoperative pain. Arquivo Brasileiro de Medicina Veterinária e Zootecnia. 66(4): 1073-1079.

4 Bednarski R.M. 2015. Dogs and Cats. In: Grimm K.A., Lamont L.A., Tranquilli W.J., Greene S.A. \& Robertson S.A. (Eds). Lumb \& Jones' Veterinary Anesthesia and Analgesia. 5th edn. Ames: Wiley Blackwell, pp.819-826.

5 Breuninger H., Hobbach P.S. \& Schimek F. 1999. Ropivacaine: a important anesthetic agent for slow infusion and other forms of tumescent anesthesia. Dermatologic Surgery. 25(10): 799-802.

6 Cabral R.R., Ciasca B.D., Oliveira V.M.C., Vaz-Curado A.P. \& Larsson M.H.M.A. 2010. Valores da pressão arterial em cães pelos métodos oscilométrico e doppler vascular. Arquivo Brasileiro de Medicina Veterinária e Zootecnia. 62(1): 64-71.

7 Cavalcante A.N., Gurrieri C., Sprung J., Schroeder D.R. \& Weingarten T.N. 2018. Isoflurane and postoperative respiratory depression following laparoscopic surgery: a retrospective propensity matched analysis. Bosnian Journal of Basic Medical Sciences. 18(1): 95-100.

8 Credie L.F.G.A., Luna S.P.L., Futema F., da Silva L.C.B.A., Gomes G.B., Garcia J.N.N. \& Carvalho L.R. 2013. Perioperative evaluation of tumescent anaesthesia technique in bitches submitted to unilateral mastectomy. BMC Veterinary Research. 9(1): 178-189.

9 Comasseto F., Rosa L., Ronchi S.J., Fuchs K., Regalin B.D., Regalin D., Padilha V. \& Oleskovicz N. 2017. Correlação entre as escalas analógica visual, da Glasgow, Colorado e Melbourne na avaliação de dor pós operatória em cadelas submetidas à mastectomia total unilateral. Arquivo Brasileiro de Medicina Veterinária e Zootecnia. 69(2): 355-363.

10 Costa Júnior J.S., Goiozo P.F.I. \& Silva E.O. 2016. Estudo epidemiológico de tumores de mama em cadelas na região do oeste paulista. Colloquium Agrariae. 12(1): 27-31.

11 Daleck C.R., Franceschini P.H., Alessi A.C., Santana A.E. \& Martins M.I.M. 1998. Aspectos clínico e cirúrgicos do tumor mamário canino. Ciência Rural. 28(1): 95-100.

12 Dumantepe M. \& Uyar I. 2015. Comparing cold and warm tumescent anesthesia for pain perception during and after the endovenous laser ablation procedure with $1470 \mathrm{~nm}$ diode laser. Phlebology. 30(1): 45-51.

13 Esteves N.A., Eneas M.D. \& Abimussi C.J.X. 2015. Tumescent local anesthesia with lidocaine 0,08\% in dog undergoing unilateral mastectomy: case report. Almanaque de Medicina Veterinária e Zootecnia. 1(1): 21-25.

14 Feitosa F.L.F. 2008. Exame físico geral ou de rotina. In: Feitosa L.F.L. (Ed). Semiologia Veterinária - A Arte do Diagnóstico. 2.ed. São Paulo: Roca, pp.65-86.

15 Firth A.M. \& Haldane S.L. 1999. Development of a scale to evaluate postoperative pain in dogs. Journal of the American Veterinary Medical Association. 214(5): 651-659.

16 Gomes L.G., Pytlak D.B., Amaral A.R.B., Sônego D.A., Monzem S., Campos G.M.D., Souza M.A., Ribeiro A.P., Flôres F.N. \& Guimarães L.D. 2018. Evaluation of postoperative residual analgesia of two solutions used for local anesthesia by tumescence in bitches who underwent a unilateral mastectomy. Acta Scientiae Veterinariae. 46: 1567. https://doi.org/10.22456/1679-9216.83159

17 Guyton A.C. \& Hall J.E. 2006. Local and humoral control of blood flow by the tissues. In: Guyton A.C. \& Hall J.E. (Eds). Textbook of Medical Physiology. 11th edn. Philadelphia: Elsevier Saunders, pp.195-203. 
18 Guyton A.C. \& Hall J.E. 2006. States of brain activity - sleep, brain waves, epilepsy, psychoses. In: Guyton A.C. \& Hall J.E. (Eds). Textbook of Medical Physiology. 11th edn. Philadelphia: Elsevier Saunders, pp.739-747.

19 Hendrickson D. \& Virgin J. 2005. Factors that affect equine wound repair. Veterinary Clinics of North America Equine Practice. 21(1): 33-44.

20 Klaumann P.R., Wouk A.F.P.F. \& Sillas T. 2008. Patofisiologia da dor. Archives of Veterinary Sciences. 3(1): 1-12.

21 Lapid O. 2011. Syringe-delivered tumescent anesthesia made easier. Aesthetic Plastic Surgery. 35(4): 601-602.

22 Martins T.L. \& Fantoni D.T. 2010. Recuperação pós-anestésica. In: Fantoni D.T. \& Cortopassi S.R.G. (Eds). Anestesia em Cães e Gatos. 2.ed. São Paulo: Roca, pp.591-604.

23 Massone F. 1988. Planos anestésicos. In: Massone F. (Ed). Anestesiologia Veterinária. Rio de Janeiro: Guanabara, pp.46-52.

24 Mitch P. \& Hellyer P. 2008. Objective categoric methods for assessing pain and analgesia. In: Gaynor J. \& Muir W.III. (Eds). Handbook of veterinary pain management. 2nd edn. St. Louis: Mosby, pp.78-109.

25 Morton C.M., Reid J., Scott E.M., Holton L.L. \& Nolan A.M. 2005. Application of scaling model to establish and validate an interval level pain scale for assessment of acute pain in dogs. American Journal of Veterinary Research. 66(12): 2154-2166.

26 Murrell J.C., Psatha E.P., Scott E.M., Reid J. \& Hellebrekers L.J. 2008. Application of a modified form of the Glasgow pain scale in a veterinary teaching centre in the Netherlands. Veterinary Records. 162(13): 403-408.

27 Oliveira Filho J.C., Kommers G.D., Masuda E.K., Marques B.M.F.P.P., Fighera R.A., Irigoyen L.F. \& Barros C.S.L. 2010. Estudo retrospectivo de 1647 tumores mamários em cães. Pesquisa Veterinária Brasileira. 30(2): 177-185.

28 Rialland P., Authier S., Guillot M., Del Castilho J.R.E., Veilleux-Lemieux D., Frank D., Gauvin D. \& Troncy E. 2012. Validation of orthopedic postoperative pain assessment methods for dogs: a prospective, blinded, randomized, placebo-controlled study. PLoS ONE. 7(11): e49480.

29 Sarandy M.M. 2007. Avaliação do efeito cicatrizante do extrato de repolho (Brassica oleracea var capitata) em ratos wistar. 49f. Viçosa, MG. Dissertação (Mestrado em Biologia Celular e Estrutural) - Programa de Pós-Graduação em Biologia Celular e Estrutural, Universidade Federal de Viçosa.

30 Silva L.D.G., Tacla M.T.G.M. \& Rossetto E.G. 2010. Manejo da dor pós-operatória na visão dos pais da criança hospitalizada. Escola Anna Nery Revista de Enfermagem. 14(3): 519-526.

31 Skarda R.T. \& Tranquilli W.J. 2007. Local anesthetics. In: Tranquilli W.J., Thurmon J.C. \& Grimm K.A. (Eds). Lumb \& Jones' Veterinary Anesthesia and Analgesia. 4th edn. Ames: Blackwell Publishing, pp.561-593. 